\title{
The Effect of Argumentation-Based Learning Environments on Pre-service Science Teachers' Conceptual Understanding and Decision Making Styles
}

\author{
Özge Baş ${ }^{1} \&$ Serkan Sevim ${ }^{2}$ \\ ${ }^{1}$ Pamukkale University, Institute of Education Sciences, Denizli, Turkey \\ ${ }^{2}$ Pamukkale University, Education Faculty, Denizli, Turkey \\ Correspondence: Serkan Sevim, Pamukkale University, Education Faculty, Denizli, Turkey. \\ Tel: 90-533-232-0355. E-mail: serkansvm@yahoo.com
}

Received: February 15, 2020

Accepted: March 10, 2020 Online Published: March 18, 2020

doi:10.5539/hes.v10n2p66

URL: https://doi.org/10.5539/hes.v10n2p66

\begin{abstract}
The aim of this study is to investigate the effect of making argumentation practices on the conceptual understanding level and decision making styles of pre-service science teachers on socio-scientific subject, genetically modified organisms (GMO). The sample of this study consists of 48 Pre-service science teachers studying in the 2nd grade of the science education department, Faculty of Education, in the 2018-1019 academic year. 24 of the pre-service science teachers are the experimental group and 24 of them are the control group. Case study was used in the study. In the experimental group; within the scope of 5E teaching model; with materials and animations containing Toulmin's argumentation model; the control group was processed with traditional teaching methods. Conceptual understanding levels of Pre-service science teachers, who constitute the experimental and control groups, about GMO before and after the teaching activities, were measured. As a data collection tool in the research; the open-ended question and likert type scale consisting of 12 items, which are based on GMO, based on expert opinions and have scope validity, is the Knowledge Test on Genetically Modified Products of University Students (KTGMOUS), pre-test and post-test. It was applied as a test. In addition, a five-point Likert-type "Decision-Making Styles Scale" consisting of 24 items was applied to the experimental group in the form of pre-test and posttest. Findings obtained at the end of the study are presented.
\end{abstract}

Keywords: socio-scientific subjects, argumentation, conceptual understanding levels, pre-service science teachers

\section{Introduction}

There is a strong link between science and society. The reason for this is the development or renewal of scientific knowledge in line with the needs of society (Sadler \& Zeidler, 2005b). "With the interaction of society and science, issues that concern both society and science", ie socio-scientific issues, have emerged (Sadler, 2004). Scientific developments on genetic engineering (stem cells, gene therapy, cloning) and ecology (global warming) can be given as examples (Topçu, 2008). Since they have both good and bad results as a result of their use, these issues create great dilemmas or contradictions in society, that is, these issues are seen as controversial issues in society. Along with the educational status of the people, the views related to socio-scientific issues are cultural, religious, political, etc. situations are also thought to affect. Since the contents of socio-scientific subjects are situations that can be encountered in daily life, teaching and understanding these subjects to students is also among the important objectives of their education (Albe, 2008; Kolsto, 2006; Walker \& Zeidler, 2007).

Genetically modified organisms (GMO), which is on the agenda in recent years, affecting both the society and the lives of individuals in the society, is one of the subjects that are handled very much (Demir \& Pala, 2007). The use of GMO can affect living health and natural life in a good or bad way. For this reason, the society should be informed about this issue. Socio-scientific issues in research has been conducted in Turkey. In some of these studies, the knowledge levels of Pre-service science teachers on cloning, genetically modified foods and genetic engineering were investigated. When the studies conducted were examined, it was determined that the knowledge levels of students, especially Pre-service science teachers and teachers about GMO were insufficient (Topçu, 2004) and they had various misconceptions (Akgün, Çinici, Demirtaş, Gülmez \& Özden, 2013; Demir \& 
Düzleyen, 2012; Erdoğan, Özel, Prokop \& Uşak, 2009; Pektaş \& Sönmez, 2017). Therefore, it is very important to eliminate the misconceptions that students, pre-service science teachers and teachers have. It has been concluded that the teachers who lead the society in cooperation with the Ministry of National Education and related institutions should be informed about biotechnology and its products (Çiçekçi, 2008).

Presently, Pre-service science teachers who will shed light on the future should be raised about the concept of GMO and its usage areas, which are frequently encountered in the field of food and health and cause frequent discussions about its use. Conceptual understanding levels of Pre-service science teachers about the subject should be sufficient so that they can raise a generation that is conscious and has the ability to make decisions on socio-scientific issues during their teaching. In this context, the immanent and new method of both the nature of science and the science curriculum emerges as argumentation. Thanks to argumentation, students develop their critical thinking skills and understand science achievements more easily.

Argumentation-based learning environments have been chosen with the idea that pre-service science teachers can eliminate their alternative structures by contributing to the discussion of GMO, which is a socio-scientific subject, with data and scientific supports (Akyüz, 2018). The argumentation; "Scientific discussion and social interaction process in which scientific claims are supported and evaluated with empirical or theoretical evidence" (Jimenéz-Aleixandre \& Erduran, 2008) in this process, students create arguments on scientific or socio-scientific issues, question the arguments and their reasons, They are expected to reach scientifically qualified explanations by evaluating the arguments created with their viewpoints (Driver, Newton \& Osborne, 2000). Creating an argument is actually a method that is frequently used in daily life. For example, it is used in discussions to support or refute our claims. Scientists construct an explanatory result of arguments in the light of theories and scientific evidence to support or refute the model or prediction (Aslan, 2014; Zhou, 2010). The Toulmin argument model (Erduran, Simon \& Osborne, 2004; Bell \& Linn, 2000; Sampson \& Clark, 2008), frequently used in science education research, states that an argument created in this context has three basic components: claim, data and justification (Toulmin, 1958).

Claims in a scientific argument; the phenomenon is supported by data consisting of examples or observations. However, the data should be justified by rules or principles to support the claim, in other words, to reveal the link between the claim and the evidence (Aslan, 2014; Tümay \& Köseoğlu, 2011; Simon, 2008; Driver \& Other, 2000). In addition to these basic components, other structures that can make more complex arguments in the model are also proposed. For example, support is the basic assumptions or theoretical expressions whose validity is widely accepted to justify the reasoning in the argument. The rebuttal indicates the limitations of the argument, pointing out situations where the claim cannot be valid. Although this is perceived as a negativity, it is an important component in determining the validity limits of the argument, predicting and answering opposite arguments, and enhancing the quality of the argument (Erduran, Simon, \& Osborne, 2004; Kaya \& Kılıç, 2008). Restrictive; it limits the argument, determines the level at which it is valid. For example; most likely, absolutely, absolutely etc. expressions reveal the framework that limits the argument.

When the literature is examined; There are many studies on the effect of argumentation practices on conceptual understanding, problem solving and decision making strategies (Aydeniz \& Doğan, 2016; Buber \& Coban, 2017; Celep, 2015; Choi, Hand \& Nam, 2011; Cin \& Turkoguz, 2013; Dawson \& Venville, 2010; Demirel, 2016; Doruk, Duran \& Kaplan, 2017; Gumrah \& Kabapınar, 2010; Kaya, 2013; Öztürk, 2013) in sample groups of various age groups. When we look at the sample groups of the studies carried out to investigate the effect of argumentation-based teaching on conceptual comprehension, it is seen that there are limited studies conducted with university students (Acar, 2008; Aydeniz \& Doğan, 2016; Çetin, 2014; Kaya, 2013; Akyüz, 2018). Therefore, in this study; Argumentation-based teaching design applications were prepared on GMO for Pre-service science teachers.

\subsection{Purpose and Importance of the Study}

The aim of this study is to determine the effect of the argumentation process practices and the use of course materials developed on the subject on the conceptual understanding level of science Pre-service science teachers on GMO and the relationship between decision making strategies on a socio-scientific subject and field knowledge. For this, the teaching of the socio-scientific subject, GMO; Instead of traditional teaching, it was provided with the use of animations and argumentation process.

The effective socio-scientific subject culture required at every stage of life is directly related to the quality of the conceptual education to be applied to students. Therefore, the contradictions and inconsistencies in their learning must be exposed and eliminated in order for the concepts to be introduced to students to be meaningful and permanent. At this point, the biggest task belongs to the teachers. One of the most important duties of teachers in 
education and training is to identify any misunderstandings in students' information and to provide the necessary conceptual change (Sevim \& Tarım, 2017; Sevim, 2013; Ayas, Ünal \& Sevim, 2004). Therefore, regardless of the branch of the teacher, especially in socio-scientific matters, teachers should basically have an intellectual knowledge. It should not be overlooked that the current misconceptions in teachers will negatively affect the conceptual development of students. For this reason, first of all, misconceptions in teachers' pre-service education should be determined and eliminated.

\section{Method}

\subsection{Research Design}

In this study, semi-experimental method with pretest-posttest control group, which is one of the experimental research models, was used. While teaching methods used in experimental and control groups are independent variables of the research, conceptual knowledge of pre-service science teachers about GMO has been determined as dependent variables of the study. Therefore, open-ended and likert-type scale was applied to the students in the experimental and control groups in order to determine and compare the effects of the teaching activities carried out on the dependent variables.

Table 1. Methods and techniques

\begin{tabular}{llll}
\hline Groups & PRE-TEST & TEACHING ACTIVITY & POST-TEST \\
\hline Control group & - KTGMOU & Traditional teaching & - KTGMOU \\
(CG) & - Open-Ended Questions & & -Open-Ended Questions \\
Experimental & - KTGMOU & Argumentation & -KTGMOU \\
group (EG) & - Open-Ended Questions & applications & -Open-Ended Questions \\
& - Decision-Making & & - Decision-Making Style Scale \\
& Style Scale & & \\
\hline
\end{tabular}

\subsection{Participants of the Study}

The universe of the study consists of 2nd grade students of the Department of Science Education of Universities in the Aegean Region. The sample consists of 48 Pre-service science teachers, including the experimental and control group studying in the 2nd grade of Pamukkale University Faculty of Education, Science Teaching Program.

\subsection{Data Collection Tool}

In the research, open-ended and likert type scales, which are specified in the following items, were used as data collection tools.

\subsubsection{Knowledge Level Test of University Students on Genetically Modified Products}

"The Knowledge Levels Test on Genetically Modified Products of University Students" is a Likert type scale consisting of a total of 18 items used by Çiftçi and Terin (2018). In order to test the reliability of the scale (questionnaire) used in the research, reliability analysis was performed with the SPSS 23 package program for the expressions used in the analyses. As a result of the analysis, Cronbach's Alpha coefficient, which gives the reliability statistics, was found 0.77 . Accordingly, it can be said that the scale used in the study is quite reliable (Kalayc1, 2006: 405).

\subsubsection{Open-Ended Questions on the Subject of GMO}

An open-ended question consisting of 12 items with a scope validity, prepared by taking the opinions of experts on the subject of GMO, was used. Questions on the scale; It is prepared according to three different achievements, which are aimed at pre-service science teachers' explanation of basic concepts and conceptual relations related to biotechnology, their awareness about genetically modified organisms (GMO), and their assessment of GMO in terms of benefit and harm. While evaluating the scale questions, the answers given by Pre-service science teachers to open-ended questions were categorized in four groups according to their level of understanding. These are; full comprehension, incomplete comprehension, poor comprehension and inability to respond. An example is given to the categorization process of Pre-service science teachers' answers to open-ended questions about GMO; If the definition is made correctly, explanation-examples are correct and given directly related to the definition, the Teacher Candidate is in the level of full understanding in the question he / she answers. If the definition has been made correctly, explanation-no sample or explanation-examples have been given correctly, but the definition has not been made, the Teacher Candidate is at the level of incomplete understanding in the question he / she answered. If a different definition is made than the scientific one, or if the 
explanation - examples are given incorrectly, the Teacher Candidate is in the level of weak understanding in the question he answers.

\subsubsection{Decision Making Style Scale}

Decision-Making Style Scale is a five-point Likert-type scale developed by Scott and Bruce (1995) and adapted to Turkish by Taşdelen (2002). The Chronbach $\alpha$ test was applied for the validity and reliability test of the scale, which was analysed in five sub-dimensions as rational, intuitive, dependent, avoidance and spontaneous-decision making style. While the overall value of the test was 0.887 , the lowest subscale value was seen in the "Dependent Decision Making Style" $(\alpha=0.760)$.

\subsection{Application Process}

The teaching activities in the implementation process of the study were carried out for 4 weeks within the scope of the course "Biology II." In the experimental group, the subject of GMO was taught with argumentation practices and the animations developed within the scope of the 5E model. Information about the activities to be done before the beginning was given. The activities to be carried out in the experimental group were explained sequentially, and then the course applications were started. After the pre-test application, the argumentation process was taught in the first week and the different achievements Sample argumentation applications were made and then 5E model application process was started. At the stage of drawing attention; Concept map (containing the concepts of gene, DNA, chromosome etc.) has been applied in order to control the preliminary information.

Then, FROM DNA to PROTEIN-3D animation was watched and the missing information and concepts in the animation were discussed. To Pre-service science teachers; " Cancer, diabetes, hereditary disease, etc. in the family, around or in itself Is there anyone with the disease? According to the responses given by the Pre-service science teachers, the answers were guided in such a way that the causes of these diseases or suggestions of solutions were directed to the answer that the genes in the organism originated. During the discovery phase, "A.1: Explains the basic concepts and conceptual relations related to biotechnology. A.2: Gains awareness of GMO. A.3: Evaluates GMO in terms of benefit and harm. "Candidates were asked to complete the relevant questions or inference sections on the activity papers by watching animations. When asked to evaluate GMO in terms of benefits and harms, in addition to animations, argumentation practices were made, and Pre-service science teachers in the computer lab were able to research and present their arguments. After each animation, explanations on gains are included in line with arguments and inferences. After all these, in the deepening stage, Pre-service science teachers were asked questions to address one of the problem situations they encounter in their daily lives, and they were provided with the information they gained about gene replacement technology and their research and thinking skills were increased. Post-test was used as an evaluation tool at the end of the course activities. To the control group; It was first applied as a pre-test. The post-test was applied by the researcher to the Pre-service science teachers after teaching the subject with traditional teaching methods.

\section{Findings}

In this section, the data obtained from the measurement tools used in the research are presented.

\subsection{Pre-service Science Teachers' Data Obtained From "Knowledge Levels Test on Genetically Modified Products of University Students"(KTGMOU)}

In this study, the results obtained from the "KTGMOU" scale applied to Pre-service science teachers as well as open-ended questions prepared to determine the knowledge levels of Pre-service science teachers about GMO products are given in Table 2, Table 3, Table 4 and Table 5. It is presented. The scale consists of 18 questions, the benefits of GMOs, loss, etc. production in Turkey. It deals with the issues. This scale was applied within the scope of pre-test and post-test.

Table 2. Comparison of the pre-test averages of the experimental and control group Pre-service science teachers on the "KTGMOU"

$(\mathrm{p}<, 05$ is significant level)

\begin{tabular}{llllll}
\hline & & & \multicolumn{3}{c}{ Independent $\mathrm{t}$ test } \\
\hline Variable & $\mathrm{N}$ & Mean & Ss & $\mathrm{t}$ & $\mathrm{P}$ \\
\hline Experimental group & 24 & 2,45 & $, 0,17$ & & \\
Control group & 24 & 2,53 & $, 0,15$ & 0,051 & 0,116 \\
\hline
\end{tabular}

According to the results in Table 2; In the pre-test, there was no statistically significant difference at the level of 
05 between the experimental and control group Pre-service science teachers' level of knowledge regarding the subject of "Genetically Modified Products" ( $\mathrm{t}=, 051 ; \mathrm{p}>, 05$ ).

Table 3. Comparison of the post-test averages of the experimental and control group Pre-service science teachers regarding "KTGMOU"

$(\mathrm{p}<, 05$ is significant level)

\begin{tabular}{llllll}
\hline & & & \multicolumn{3}{c}{ Independent t test } \\
\hline Variable & $\mathrm{N}$ & Mean & Ss & $\mathrm{t}$ & $\mathrm{P}$ \\
\hline Experimental group & 24 & 2,68 & $, 0,15$ & & \\
Control group & 24 & 2,56 & $, 0,19$ & 0,325 & 0,020 \\
\hline
\end{tabular}

According to the results in Table-3; In the post-test, there was a statistically significant difference at the level of 05 between the knowledge levels of the pre-service and control group Pre-service science teachers on the subject of "Genetically Modified Products" ( $\mathrm{t}=, 325 ; \mathrm{p}<, 05)$. This situation is in favor of the experimental group. While the average score of the experimental group Pre-service science teachers was 2.68, the average score of the control group Pre-service science teachers was 2.56. In this case, it was observed that the Pre-service science teachers were more successful than the pre-control teachers.

Table 4. Comparison of the pre-test and post-test averages of the Pre-service science teachers of the experimental group on the "KTGMOU"

\begin{tabular}{llllll}
\hline & & & \multicolumn{3}{c}{ Independent t test } \\
\hline Variable & N & Mean & Ss & t & P \\
\hline Experimental group & 24 & 2,45 & $, 0,17$ & & \\
Control group & 24 & 2,68 & $, 0,15$ & 0,045 & 0,0001 \\
\hline
\end{tabular}

$(\mathrm{p}<, 05$ is significant level)

According to the results in Table 4; There was a statistically significant difference at the level of 05 between the pre-test and post-test genetically modified products of the experimental group Pre-service science teachers at level $05(\mathrm{t}=0.045 ; \mathrm{p}<, 05)$. This difference is in favour of the post-test. While the pre-test averages of the pre-test teachers were 2.45 , the post-test averages increased to 2.68 . Based on all these analyses, argumentation applications within the scope of $5 \mathrm{E}$ model; it was concluded that Pre-service science teachers had an effect on "KTGMOU".

Table 5. Comparison of the pre-test-post-test averages of the Pre-service science teachers of the control group on the "KTGMOU"

$(\mathrm{p}<, 05$ is significant level)

\begin{tabular}{llllll}
\hline & & & \multicolumn{3}{c}{ Independent t test } \\
\hline Variable & N & Mean & Ss & t & P \\
\hline Experimental group & 24 & 2,53 & $, 0,15$ & & \\
Control group & 24 & 2,11 & $, 0,28$ & 0,911 & 0,546 \\
\hline
\end{tabular}

According to the results in Table 5; There was no statistically significant difference at the level of 05 between the pre-test and post-test genetically modified products of experimental group pre-service science teachers at level $05(\mathrm{t}=0.911 ; \mathrm{p}>, 05)$.

\subsection{Data from Open-Ended Questions}

Open-ended questions; Prepared to measure the level of knowledge of pre-service science teachers about the acquisitions of "basic concepts about biotechnology, awareness of GMO, benefits and harms of GMO". It was applied twice before and after the application and consists of 12 questions in total. An example of the analysis of open-ended questions and the findings obtained from the scale are presented in Table 6, Table 7 and Table 8.

For example, the analysis of the answers to a question asked for Acquisition 1 is presented below. A sample answer was given for each category. Therefore, the analysis of open-ended questions was done in this way.

A.1: Explains the basic concepts and conceptual relations related to biotechnology.

Question 3: Briefly describe GMO. Describe your definition. 
Complete understanding: Pre-service science teachers are at full understanding if they answer the question as follows.

"The concept of 'Genetically Modified Organism' is used for plants, animals, or microorganisms whose specific characteristics are altered by transferring genes from one species or a species other than it. For example; Recombinant plasmid DNA can be produced by the non-insulin-producing bacterial cell when the gene responsible for producing the hormone insulin in humans is cut off by the restriction enzyme and added to the plasmid DNA from the bacterial cell with the enzyme ligase."

Missing Information: Pre-service science teachers are in the level of incomprehension if they answer the question as follows.

"It is the process of transferring a gene to a living being from a species other than its own."

Weak Understanding: If Pre-service science teachers answer the question as below, they are at a poor understanding level.

"Deviations from their real state as a result of the genetics of foods being played."

Not Responding: Pre-service science teachers are at the level of unresponsive if they leave the question blank.

Table 6. Comparison of the first and last profiles of Pre-service science teachers in both groups about the acquisition of 1 (A.1)

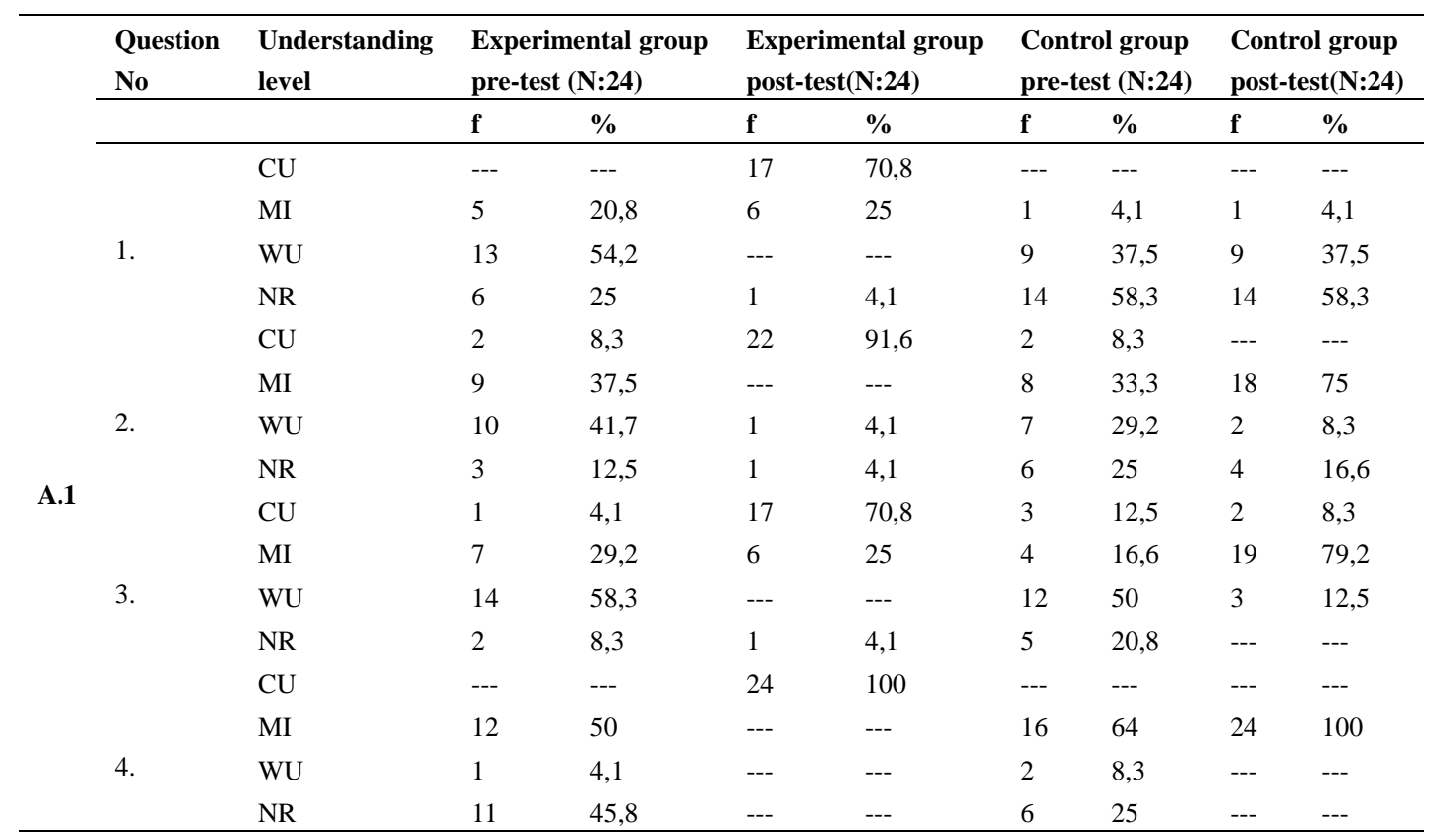

(CU: Completely Understanding, MI: Missing Information, WU: Weak Understanding, NR: Not Responding)

As seen in Table-6; It was observed that almost none of the experimental and control group Pre-service science teachers could answer the questions covering the acquisition of A.1 before the application at full comprehension level. (For the second question, both groups answered 8.3\%; for the third question, experimental group Pre-service science teachers answered 8.3\%, and control group Pre-service science teachers answered 12.5\%). It has been observed that the Pre-service science teachers' comprehension level rates reached up to $100 \%$ after the application $(70.8 \%$ for the first and third questions, $91.6 \%$ for the second questions, $100 \%$ for the fourth questions). As a result, it is in question that almost all levels of poor comprehension and non-responsiveness reach complete and incomplete comprehension levels after application. (Some questions are $4.1 \%$ ). On the other hand, there is no change in the levels of comprehension of the control group Pre-service science teachers after the application, and there is a decrease in the levels of full comprehension in questions two and three. In general terms, it was observed that they respond at incomplete and weak comprehension levels.

At the same time, when the answers given by Pre-service science teachers are examined;

Before describing EG-6, "Briefly describe biotechnology. Explain your definition briefly. "While answering the number one question, "It is the field of study carried out by combining the fields of biology and 
technology. "; After the application, "By utilizing many engineering branches, DNA technology is all the technologies used to develop plants, animals and microorganisms, to obtain or develop substances that are not as much, nonexistent or scarce." It has reached the level of full understanding from weak understanding.

EG-2 Teacher Candidate asked "What is the expansion of GMO?" Briefly describe GMO. Explain your definition. "In the third question, we can say" Genetically modified foods / Playing with the genetic structure of foods, and therefore deviations from the natural state. "After the application, it is called" GMO / Creatures- playing with genetics of organisms and making it better. Ligase and restriction enzymes are used. The gene that we want is cut from the living creature with the related gene restriction enzyme and adhered to another creature by the enzyme. The transferred creature can fulfil the task of the gene we want. For example, in this way, hormone drugs are produced in this way", from the weak understanding level to the full understanding level.

The EG-16 Teacher Candidate list most of the GMO products that were successfully applied, covering A.1 prior to the application. "While answering the question number four, "Chips, ready fried potatoes"; after the application, "Egypt, soy, insulin hormone, vaccine, vitamin tablets, fruit yogurt, papaya" response has reached the level of full understanding from weak understanding.

While the CG-19 Teacher Candidate cannot answer the question before the application; after the application, "Soy, papaya, tomato, wheat, rice" responded to the level of incomplete understanding.

Table 7. Comparison of the last profiles of Pre-service science teachers in both groups A.2

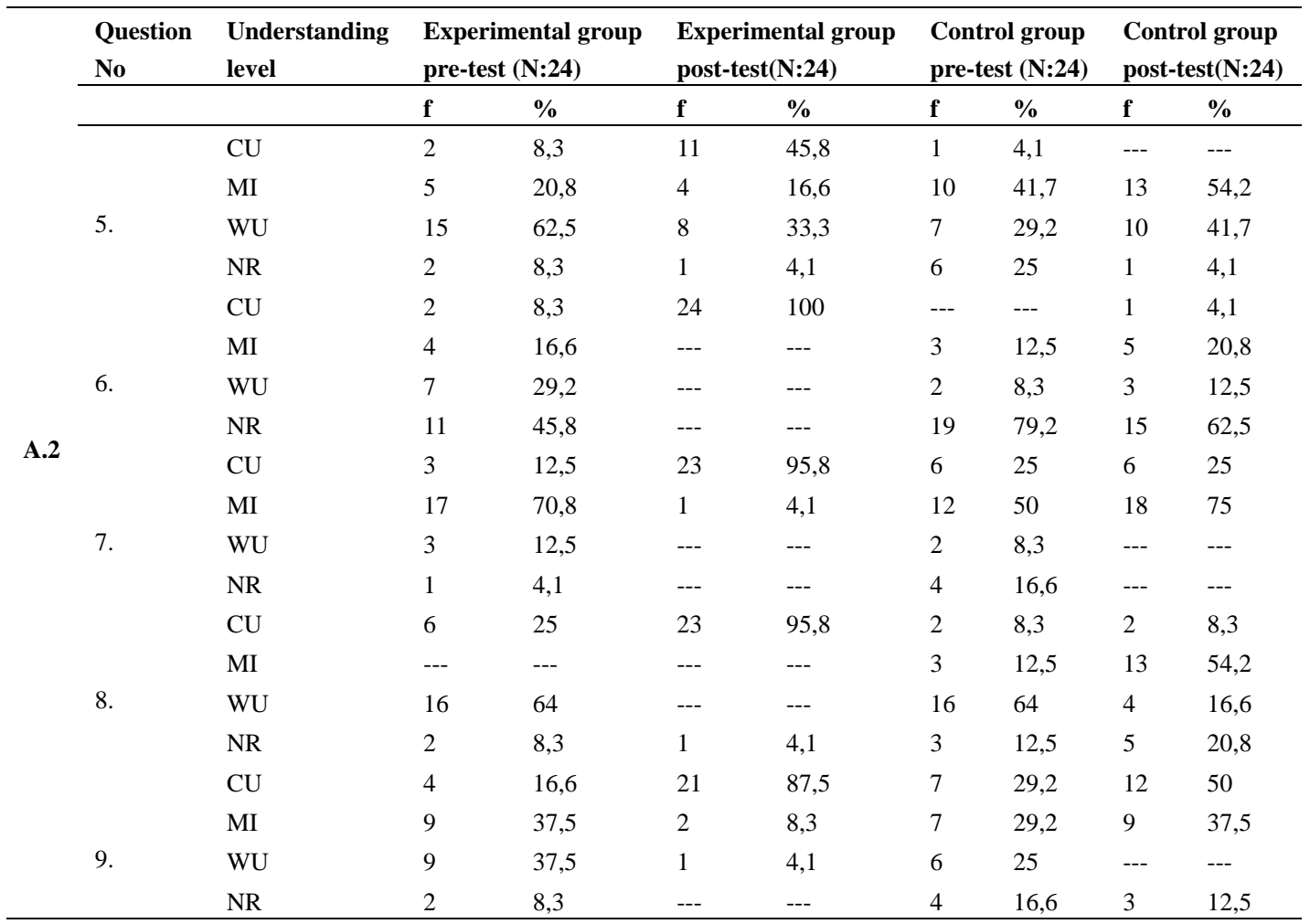

(CU: Completely Understanding, MI: Missing Information, WU: Weak Understanding, NR: Not Responding)

As seen in Table 7; Experimental group Pre-service science teachers were not able to answer the questions covering the A.3 acquisition at the level of full comprehension; It was observed that the Teacher Candidate teachers responded at $4.1 \%$ and $16.6 \%$ at full comprehension level. It has been observed that the experimental group Pre-service science teachers' understanding level has reached up to $87.5 \%$ after the application. (58.3\% for the first question, $87.5 \%$ for the second question and $25 \%$ for the third question). As a result; it was found that the level of inability to respond completely was eliminated, and the levels of weak comprehension decreased and reached levels of incomplete comprehension and full comprehension. It was observed that the Pre-service science teachers were not able to answer the full comprehension level in question number ten after the application, $12.5 \%$ in the eleven question and $25 \%$ in the twelve question. Based on the findings, it was observed 
that the conceptual perception levels of the Pre-service science teachers were higher than the control group. At the same time, when the answers given by Pre-service science teachers are examined;

EG-1 Teacher Candidate, "How do GMO products affect human health? Explain your answer with examples. "While answering the question number ten, "Negative effects. "Before the application; "It can affect both good and bad after application. Good: cancer drugs, growth hormone... products made in the health field are beneficial to human health. Bad: antibiotic resistant environment, allergic reactions, obesity, reduction of reproductive cells.

EG-22 Teacher Candidate said, "IS GMO useful or harmful? Please indicate your reason for the election and explain your reason for your reason. However, the harmful effects are more talked about. "After the application; "It is both useful and harmful. The feature may change depending on the area and purpose used. It is beneficial in terms of developments in the field of health. Because it is used for finding solutions to many diseases. However, there are also harms due to resistance against bacteria and allergic and carcinogenic effects. I am extremely against the use in the agriculture or food sector. "It has reached the level of full understanding from the level of incomplete understanding.

CG-4 Teacher Candidate, "How do GMO products affect human health before the application? Explain your answer with examples. "While answering the question number ten, " There may be effects on human health both badly and well. "; After the application, he responded, "It affects human health in a bad way. In this example; We can see that the CG-4 Teacher Candidate focused only on the bad aspects of GMO after the application.

While the CG-19 Pre-service science teachers' cannot answer the question before the application, after the application; "It is both beneficial and harmful. It is beneficial in terms of developments in the field of health. However, it has a harmful effect due to the side effects it shows even as a result of its use in the field of health. "Reached the level of full understanding.

Considering the examples and values in the table above, it can be said that teaching with argumentation practice within the scope of 5E model is very effective in developing the conceptual understanding levels of Pre-service science teachers about GMO.

Table 8. Comparison of the first and last profiles of Pre-service science teachers in both groups regarding the acquisition of 3 (A.3)

\begin{tabular}{|c|c|c|c|c|c|c|c|c|c|c|}
\hline & \multirow[t]{2}{*}{ Question No } & \multirow[t]{2}{*}{$\begin{array}{l}\text { Understanding } \\
\text { level }\end{array}$} & \multicolumn{2}{|c|}{$\begin{array}{l}\text { Experimental group } \\
\text { pre-test }(\mathrm{N}: 24)\end{array}$} & \multicolumn{2}{|c|}{$\begin{array}{l}\text { Experimental group } \\
\text { post-test(N:24) }\end{array}$} & \multicolumn{2}{|c|}{$\begin{array}{l}\text { Control group } \\
\text { pre-test }(\mathrm{N}: 24)\end{array}$} & \multicolumn{2}{|c|}{$\begin{array}{l}\text { Control group } \\
\text { post-test(N:24) }\end{array}$} \\
\hline & & & f & $\%$ & f & $\%$ & $\mathbf{f}$ & $\%$ & f & $\%$ \\
\hline \multirow{12}{*}{ A.3 } & \multirow{4}{*}{10} & $\mathrm{CU}$ & --- & --- & 14 & 58,3 & 1 & 4,1 & --- & --- \\
\hline & & MI & 1 & 4,1 & 7 & 29,2 & 2 & 8,3 & 1 & 4,1 \\
\hline & & WU & 18 & 75 & 3 & 12,5 & 14 & 58,3 & 21 & 87,5 \\
\hline & & NR & 5 & 20,8 & --- & --- & 7 & 29,2 & 2 & 8,3 \\
\hline & \multirow{5}{*}{11} & $\mathrm{CU}$ & --- & --- & 21 & 87,5 & 1 & 4,1 & 3 & 12,5 \\
\hline & & MI & --- & --- & 2 & 8,3 & 5 & 20,8 & 5 & 20,8 \\
\hline & & WU & 9 & 37,5 & 1 & 4,1 & 5 & 20,8 & 9 & 37,5 \\
\hline & & NR & 15 & 62,5 & --- & --- & 13 & 54,2 & 7 & 29,2 \\
\hline & & $\mathrm{CU}$ & --- & --- & 6 & 25 & 4 & 16,6 & 6 & 25 \\
\hline & \multirow{3}{*}{12} & MI & 2 & 8,3 & 14 & 58,3 & 6 & 25 & 10 & 41,7 \\
\hline & & WU & 16 & 64 & 4 & 16,6 & 12 & 50 & 6 & 25 \\
\hline & & NR & 6 & 25 & --- & --- & 2 & 8,3 & 2 & 8,3 \\
\hline
\end{tabular}

(CU: Completely Understanding, MI: Missing Information, WU: Weak Understanding, NR: Not Responding)

As seen in Table 8; Experimental group Pre-service science teachers were not able to answer the questions covering A.3 acquisition at the level of full comprehension; It was observed that the Teacher Candidate teachers responded at $4.1 \%$ and $16.6 \%$ at full comprehension level. It has been observed that the experimental group Pre-service science teachers' understanding level has reached up to $87.5 \%$ after application. $(58.3 \%$ for the first question, $87.5 \%$ for the second question and $25 \%$ for the third question). As a result; it was found that the level of inability to respond completely was eliminated, and the levels of weak comprehension decreased and reached the levels of incomplete comprehension and full comprehension. It was observed that the Pre-service science teachers were not able to answer the full comprehension level in question number 10 , and $12.5 \%$ in the eleven 
question and $25 \%$ in the twelve question. Based on the findings, it was observed that the conceptual perception levels of the Pre-service science teachers were higher than the control group. At the same time, when the answers given by pre-service science teachers are examined;

DG-1 teacher candidate, "How do GMO products affect human health? Explain your answer with examples. "While answering the question number ten, "Negative effects. "Before the application; "It can affect both good and bad after application. Good: cancer drugs, growth hormone... products made in the health field are beneficial to human health. Bad: antibiotic resistant environment, allergic reactions, obesity, reduction of reproductive cells.

DG-22 teacher candidate said, "Is GMO useful or harmful? Please indicate your reason for selection and explain your reason for your choice. "To question number twelve, before the application, "There are benefits and harms. However, the harmful effects are more talked about. "After the application; "It is both useful and harmful. The feature may vary depending on the area and purpose used. It is beneficial in terms of developments in the field of health. Because it is used for finding solutions to many diseases. However, there are also harms due to resistance against bacteria and allergic and carcinogenic effects. I am extremely against the use in the agricultural or food sector. "It has reached the level of full understanding from the level of incomplete understanding.

$K G-4$ teacher candidate, "How do GMO products affect human health before the application? Explain your answer with examples. "While answering the question numbered ten, "Human health may have a negative effect in a good way. After the application, he responded, "It affects human health in a bad way. In this example; We can see that the CG-4 teacher candidate focused only on the bad aspects of GMO after the application. While the KG-19 teacher candidate cannot answer the question before the application, after the application; "It is both beneficial and harmful. It is beneficial in terms of developments in the field of health. However, it has a harmful effect due to the side effects it shows even as a result of its use in the field of health. "Reached the level of full understanding.

Considering the examples and values in the table above, it can be said that teaching with argumentation practice within the scope of $5 \mathrm{E}$ model is very effective in developing the conceptual understanding levels of pre-service science teachers about genetically modified organisms

\subsection{Findings Regarding Pre-service Science Teachers' Decision Making Styles}

This scale was applied to investigate the effects of argumentation practices, which is the sub-problem of the study, on the decision-making styles of experimental group pre-service science teachers. The data obtained from this scale applied to pre-and post-test pre-test teachers were presented in Table 9, Table 10, Table 11 and Table 12.

Table 9. Comparison of pre-post test averages of rational decision-making styles of experimental group

\begin{tabular}{lllllll}
\hline Pre/Post-test & & $\mathrm{N}$ & $X$ & $\mathrm{Sd}$ & $\mathrm{F}$ & $\mathrm{p}$ \\
\hline Rational Decision-Making Style & Pre-test & 24 & 4,18 & 0,53 & 46,204 & 0,0001 \\
& Post-test & 24 & 4,95 & 0,11 & & \\
\hline
\end{tabular}

$(\mathrm{p}<, 05$ is significant level $)$

According to the results in Table 9; When the Rational Decision-Making Style is examined; While the pre-test Pre-service science teachers had an average of 4.18 , the post-test increased to 4.95 , and there was a positive change. A statistically significant difference was found ( $\mathrm{f}=46,204, \mathrm{p}=0,0001)$. After the application, it was determined that Pre-service science teachers showed improvement in rational decision making styles.

Table 10. Comparison of the pre-post test average of intuitive decision making styles of experimental group pre-service science teachers

\begin{tabular}{|c|c|c|c|c|c|c|}
\hline & & \multirow{3}{*}{$\frac{X}{3,83}$} & \multirow{3}{*}{$\begin{array}{l}\mathrm{Sd} \\
0,64 \\
0,66\end{array}$} & & \\
\hline \multirow{2}{*}{$\begin{array}{l}\text { Pre/Post-test } \\
\text { Heuristic Decision-Making Style }\end{array}$} & \multirow{2}{*}{$\begin{array}{l}\text { Pre-test } \\
\text { Post-test }\end{array}$} & & & & \multirow{2}{*}{0,212} & \multirow{2}{*}{0,0001} \\
\hline & & $\frac{N}{24}$ & & & & \\
\hline
\end{tabular}

$(\mathrm{p}<, 05$ is significant level $)$

When the Heuristic Decision-Making Style is examined according to the results in Table 10; In the pre-test results, Pre-service science teachers had an average of 3.83, post-test averages decreased to 2.77 and a 
statistically significant difference was found ( $f=0.212, p=0.0001$ ). It was found that Pre-service science teachers showed negative development in heuristic decision making styles after the application.

Table 11. Comparison of pre-post test averages regarding dependent decision-making styles of experimental group pre-service science teachers

\begin{tabular}{lllllll}
\hline Pre/Post-test & & N & $X$ & SD & F & p \\
\hline Dependent Decision-Making Style & Pre-test & 24 & 3,60 & 0,68 & 0,062 & 0,0001 \\
& Post-test & 24 & 2,58 & 0,58 & & \\
\hline
\end{tabular}

$(\mathrm{p}<, 05$ is significant level)

When the Dependent Decision-Making Style is examined according to the results in Table-11; While the pre-test teachers had an average of 3.60, the pre-test averages decreased to 2.58 and a statistically significant difference was found ( $f=0.062, p=0.0001$ ). After the application, it was found that Pre-service science teachers showed negative development in dependent decision making styles.

Table 12. Comparison of pre-post test averages regarding avoidance decision-making styles of experimental group pre-service science teachers

\begin{tabular}{llllllll}
\hline Pre/Post-test & & $\mathrm{N}$ & $X$ & $\mathrm{Sd}$ & $\mathrm{f}$ & $\mathrm{p}$ \\
\cline { 2 - 7 } & Avoidance Decision-Making Style & Pre-test & 24 & 2,78 & 0,81 & \multirow{2}{*}{2,325} & \multirow{2}{*}{0,0001} \\
& Post-test & 24 & 1,78 & 0,57 & & \\
\hline
\end{tabular}

$(\mathrm{p}<, 05$ is significant level)

When Avoidance Decision-Making Style is examined according to the results in Table-12; While pre-test Pre-service science teachers had 2.78 averages, post-test averages decreased to 1.78 and a statistically significant difference was found $(\mathrm{f}=2.325, \mathrm{p}=0.0001)$. After the application, it was found that Pre-service science teachers showed negative development in avoidance decision-making style.

Table 13. Comparison of pre-post test averages regarding spontaneous-instant decision-making styles of experimental group pre-service science teachers

\begin{tabular}{lllllll}
\hline Pre/Post-test & & $\mathrm{N}$ & $X$ & $\mathrm{Sd}$ & $\mathrm{f}$ & $\mathrm{p}$ \\
\hline \multirow{2}{*}{ Spontaneous-Instant Decision-Making Style } & Pre-test & 24 & 3,50 & 0,88 & \multirow{2}{*}{5,556} & \multirow{2}{*}{0,0001} \\
\cline { 2 - 6 } & Post-test & 24 & 1,47 & 0,54 & & \\
\hline
\end{tabular}

$(\mathrm{p}<, 05$ is significant level)

When the Spontaneous-Instant Decision-Making Style is examined according to the data in Table 13; In the pre-test results, Pre-service science teachers had an average of 3.50, post-test averages decreased to 1.47 and a statistically significant difference was found $(\mathrm{f}=5.556, \mathrm{p}=0.0001$ ). After the application, it was found that Pre-service science teachers showed negative development of spontaneous-instant decision making style.

Table 14. Comparison of the pre-post test averages of the pre-service science teachers of the experimental group

\begin{tabular}{lllllll}
\hline Pre/Post-test & & $\mathrm{N}$ & $X$ & $\mathrm{Sd}$ & $\mathrm{f}$ & $\mathrm{p}$ \\
\hline \multirow{2}{*}{ Decision-Making Styles Scale Overall } & Pre-test & 24 & 3,58 & 0,45 & \multirow{2}{*}{2,853} & 0,0001 \\
& Post-test & 24 & 2,71 & 0,26 & & \\
\hline
\end{tabular}

$(\mathrm{p}<, 05$ is significant level)

Before starting the teaching activities, it was observed that the average of each decision making styles of the experimental group Pre-service science teachers was close to each other. When the pre-test and post-test results were examined, it was observed that the pre-test Pre-service science teachers switched from intuitive, dependent, avoidance and spontaneous decision making styles to rational decision making style. Considering the examples and the values in the table above, it can be said that teaching with argumentation-based course material is very effective not only in improving the conceptual understanding levels of the Pre-service science teachers about GMO, but also in developing decision-making styles.

\section{Discussion, Results and Suggestions}

In this chapter; Based on the findings given in the previous section, the resulting results are discussed and 
presented. When the pre-test results of "Knowledge Levels Test on Genetically Modified Products of University Students" were examined, there was no statistically significant difference at the level of .05 between the experimental and control group Pre-service science teachers' knowledge levels $(t=, 051 ; p>, 05 p=0.116)$. After the application, the test average of the pre-service science teachers increased from 2.45 to 2.68 . There was a statistically significant difference between the pre-test and post-test results at level $.05(\mathrm{t}=0.045 ; \mathrm{p}<, 05 \mathrm{p}=$ 0.0001). This difference is in favour of the post-test. After the application with traditional teaching methods, it was found out that the pre-test average of the Pre-service science teachers decreased from 2.53 to 2.11 in the post-test. It was observed that there was no statistically significant difference at the level of 05 between the pre-test and post-test results of the control group Pre-service science teachers $(t=0.911 ; p>, 05 p=0.546)$. As a result, argumentation applications within the scope of 5E model; It can be said that Pre-service science teachers are largely successful in increasing their knowledge level about GMO products since active participation in the lesson, discovering information and creating a scientific discussion environment enables them to construct the information. Similar results were found in similar studies on argumentation-based teaching (Acar, 2008; Akyüz, 2018).

According to the results obtained from the tests and interviews applied to Pre-service science teachers, in the study conducted by Akyüz with pre-service science teachers, it was concluded that the Pre-service science teachers' knowledge levels in GMO-related concepts were insufficient before the applications. In addition, according to the pre-test results, pre-service science teachers mix GMO, hormonal food and chemical products with each other. Similar results are observed in this study. It has been concluded that learning environments created based on argumentation technique have an impact on Pre-service science teachers' participation in discussions with argument data and reasons, and their conceptual understanding. In addition to that, when the field-literature is examined, Celep (2015), who is working on subjects other than GMO, also has a higher understanding of the concepts of gases in the experimental group students studying in the argumentation-based interrogatory education model. and misconceptions about the subject. It was determined to be less statistically. In the study conducted by Aydeniz and Doğan (2016) with Pre-service science teachers on chemical dissolution, it was concluded that the experimental group students were significantly more successful than the control group in the applied test results and also in the final exam. Nussbaum and Sinatra (2003), in their study of 41 high school students, addressed the issue of Newton's law of gravity in two groups as experimental and control groups. Considering the results of the 22 -item multiple choice basic physics knowledge measurement test used as a data collection tool; It was concluded that the students of the experimental group, where they conduct argumentation-based teaching, focus on the important aspects of the problems compared to the control group students, and that they have more superiority in increasing the conceptual relationships. Chen and She (2012) focused on seven subjects in the science of physics in their work with eighth grade students (seventy-four consisting of 150 people in the experimental group and seventy-six in the control group). As the method, argumentation-based learning was used in the experimental group and traditional method was used in the control group. In this study, the concept and argumentation tests on the subject were applied as pre-test and post-test. After the applications they did with the experimental group, it was concluded that there were significant advances in the conceptual change of the experimental group students compared to the control group students. In addition, it was concluded that the students of the experimental group included in the argumentation process answered the concepts asked afterwards more accurately than before the discussion. In the study conducted by Acar (2008) with 125 pre-service science teachers, argumentation-based teaching practices on physics subjects were made. Acar used "Argumentation skills and conceptual knowledge tests" as a data collection tool in his study and reached the conclusion that the targeted concepts of teacher candidates in physics subjects that are the subject of the study have been developed.

When the analysis of open-ended questions was analysed, it was observed that almost none of the experimental and control group Pre-service science teachers were able to answer questions covering the acquisition of A.1 "explains the basic concepts and conceptual relations related to biotechnology." It has been observed that the experimental group Pre-service science teachers' comprehension levels reach up to $100 \%$ after the application. If we touch on the changes in some questions; In the first and third questions, respectively, "Briefly define biotechnology and briefly describe your definition. What is the expansion of GMO? and describe GMO briefly, explain your definition. "The level of weak understanding is completely eliminated. In the fourth question, in which there is no pre-test teacher candidate who can answer full comprehension level, "List most of the GMO products that have been applied successfully." The reason they reached $100 \%$ full comprehension level is that the animations organized are both in the health and food sector and the Pre-service science teachers in many areas during the argumentation process. they do research. As a result, in the general sense, in questions covering A.1, Pre-service science teachers' weak comprehension and non-response levels reach almost complete and 
incomplete comprehension levels after the application. On the other hand, the control group Pre-service science teachers did not observe any change in the level of comprehension after the application, and in the questions number two and three, "Briefly describe the genetic engineering and briefly explain your definition. What is the expansion of GMO? and define GMO briefly, explain your definition. "There is a decrease in the levels of full understanding.

It was observed that the Pre-service science teachers of the control group responded to the questions in general incomplete and weak comprehension levels. In the fourth question, in which there is no pre-test teacher candidate who can answer full comprehension level, "List most of the GMO products that are successfully applied." and lack of room for questioning and still being influenced by the media. In a similar study, this situation was mentioned. In the study conducted by Koçyiğit (2015), it was determined that the pre-service science teachers' attitudes towards GMO and their insufficient knowledge levels were not influenced by gender and age factors, and it was concluded that one of the important reasons for this was the biased publications made by the written or visual media used as a source of information.

It was observed that the vast majority of the pre-service and control group Pre-service science teachers could not answer the questions covering the acquisition of A.2 "Explains the basic concepts and conceptual relations related to biotechnology". (It was observed that the pre-service and control group Pre-service science teachers responded at a full understanding level in the ratio of $4.1 \%$ to $29.2 \%$ ). It was observed that most of the experimental group Pre-service science teachers' weak comprehension and unresponsiveness levels were eliminated and they reached full and incomplete comprehension levels. (45.8\% for the fifth question, $100 \%$ for the sixth question, $95.8 \%$ for the seven and eighth question, and $87.5 \%$ for the ninth question). If we touch on the changes in some questions; In the fifth question, "Can consumption of GD foods destroy human genes? Explain your choice for reasons. "The poor understanding level of pre-test teachers, which was $62.5 \%$ in the pre-test, decreased to $33.3 \%$ in the post-test. This change is below desired. The mistakes of pre-service science teachers about whether the products consumed are related to human genes or not cannot be eliminated. In addition, it was determined that all of the pre-service Pre-service science teachers were a biotechnological process in the brewing process included in the sixth question, and they could make an accurate explanation, grasp and explain the differences between hormonal and GMO products, and have an idea about why GMO products are produced. On the other hand, it was observed that the control group Pre-service science teachers did not change the level of comprehension except for the question number nine after the application, but they responded in general incomplete and weak comprehension levels. In the eighth question, the control group Pre-service science teachers' weak comprehension levels decreased from $64 \%$ to 16.6 , but it was concluded that they understood that hormonal and GMO products were different from each other, but because they could not make sufficient explanation, they responded at the level of incomplete understanding. In general terms, it was observed that Pre-service science teachers of the control group did not reach sufficient levels of understanding in explaining the concept relations related to biotechnology.

Experimental group Pre-service science teachers could not answer the questions that cover the acquisition of A.3 "Evaluates GMO in terms of benefit and harm." It was observed that the Teacher Candidate teachers responded at $4.1 \%$ and $16.6 \%$ at full comprehension level. It has been observed that the experimental group Pre-service science teachers' understanding level has reached up to $87.5 \%$ after the application. (58.3\% for the tenth question, $87.5 \%$ for the eleventh question and $25 \%$ for the twelfth question). As a result; it was found that the level of inability to respond completely was eliminated, and the levels of weak comprehension decreased and reached levels of incomplete comprehension and full comprehension. It was observed that the Pre-service science teachers were not able to answer the full comprehension level in question number ten after the application, $12.5 \%$ in the eleven question and 25\% in the twelve question. Based on the findings, it was observed that the conceptual perception levels of the Pre-service science teachers were higher than the control group. If we touch on the changes in some questions; In the tenth question in the pre-test, pre-test Pre-service science teachers asked "How do GMO products affect human health? Explain your answer with examples. "It is at the level of weak understanding by $75 \%$. In other words, they only mentioned the negative effects in the question. In the last test, this rate decreased to $12.5 \%$. It has been observed that students who have a complete and incomplete comprehension level talk about the use of GMO in the treatment of diseases as well as its side effects and the negative effects of its use in the food sector as a result of developments in the health sector. In the control group, it was observed that the level of weak understanding increased from $58.3 \%$ to $87.5 \%$ in the post-test application. It was observed that there was an increase in the opinions of the control group Pre-service science teachers that the use of GMO is only harmful to human health. In relation to the tenth question, only $25 \%$ of the Pre-service science teachers in both groups were able to make sufficient explanation by addressing both the benefits and 
harms of the two in question number 12, which addresses their views on the benefits or harms of GMO. In addition, it was observed that $58.3 \%$ of the experimental group Pre-service science teachers were at the level of incomplete understanding of $41.7 \%$ of the control group Pre-service science teachers. In other words, they think that it is both beneficial and harmful, but they could not make sufficient explanation.

It is thought that the pre-service science teachers in both groups prior to the application were lacking in their knowledge of GMO, and that they were influenced by the media or the environment they lived in. However, in the post-application post-test, after the increase in the knowledge level of the Pre-service science teachers about GMO, the opinions of GMOs about the benefits and harms of the GMO; It was observed that they first determined the area of use and then made possible inferences. While specifying the areas of use, they explained their useful and harmful aspects quite clearly, not only in the food sector but also in the field of health, as in the preliminary tests. This means that the Pre-service science teachers' teachers benefit from the animations during the applications, they conduct research by following the scientific research process effectively in the argumentation process, and compete their arguments; it is clear evidence that it eliminates information gaps and negative attitudes and that the level of conceptual understanding of GMO is improving.

In this study, Pre-service science teachers were asked to decide on the benefits and harms of GMO. Before starting the teaching activities, the experimental group Pre-service science teachers whose rational, intuitive, dependent, avoidance, spontaneous-decision making averages are close to each other; Looking at the test results after applying the teaching activities, while positive change was observed in the rational decision making style; Negative changes have been observed in intuitive, dependent, avoidance and spontaneous decision-making styles. Looking at these results; argumentation practices revealed that Pre-service science teachers adopt rational decision-making style in the decision-making process, that is, they evaluate the alternatives and make decisions by making researches. In this study; As argumentation practices provide the opportunity for scientific discussion and providing information from multiple sources, as in the results in the literature, Pre-service science teachers' knowledge levels about GMO increased and their decision-making skills improved rationally.

Many studies have shown that the study of students' argumentation on sociological issues improves their decision making skills (Kortland, 1996; Nicaloau et al., 2009; Ratcliffe 1996; Sadler \& Zeidler, 2005). For example; As a result of the study conducted by Sadler and Zeidler (2005), it was concluded that the students' rational reasoning rate was higher. $\mathrm{n}$ the study of Kardaş (2013), it was aimed that the students should carry out the unit "Let's Travel the World of Living Things" within the scope of science and technology lesson with Argumentation-Oriented Teaching activities; investigated the effect on decision making skills. As a result of this experimental study with the students attending the fifth grade, the experimental group showed that the decision-making skills of the students improved. Also; the study of Dori, Tal and Tsaushu in 2003, it came to the conclusion that the argumentation method in science teaching improved students' thinking skills in the decision-making process.

In this section, some suggestions are presented based on the results of the research reached in the current study and summarized in the previous section.

- If this study can be carried out for a long period of time in different gains, better results can be obtained.

- If the argumentation process is applied on different samples, the sample can work more efficiently because it dominates the process.

- In this way, a study can be conducted with students of different age groups. Thus, the effects of the argumentation process will also be revealed longitudinally.

- Comparative studies can be carried out by preparing activities using different approaches or methods than argumentation. Thus, the most appropriate method or approach can be determined.

\section{Acknowledgments}

This is an TÜBİTAK 2209-A University Students Research Projects Support Program funded research, Project Number: 1919B011800625e.

\section{References}

Acar, O. (2008). Argumentation Skills and Conceptual Knowledge Of Undergraduate Students In A Physics By Inquiry Class. Unpublished doctoral dissertation. The Ohio State University, Ohio.

Acar, O., Turkmen, L., \& Roychoudhury, A. (2010). Student difficulties in socio-scientific argumentation and decision-making research findings: Crossing the borders of two research lines. International Journal of Science Education, 32(9), 1191-1206. https://doi.org/10.1080/09500690902991805 
Akgün, A., Çinici, A., Demirtaş, F., Gülmez, H., \& Özden, M. (2013). 8. sınıf öğrencilerinin genetiği değiştirilmiş organizmalar (GDO) hakkındaki bilgi düzeyleri ve biyoteknolojiye yönelik tutumlarının incelenmesi. Adlyaman Üniversitesi Ë̆itim Bilimleri Dergisi, 3(2), 94-115.

Akyüz, M. (2018). Argümantasyon Tabanlı Öğrenme Ortamlarının Sınıf Öğretmen Adaylarının Kavramsal Anlamalarına Etkisi Genetiği Değiştirilmiş Organizmalar Örneği. Yüksek Lisans Tezi. Karadeniz Teknik Üniversitesi Eğitim Bilimleri Enstitüsü İlköğretim Anabilim Dalı Sınıf Öğretmenliği Eğitimi Bilim Dalı, Trabzon.

Albe, V. (2008). When scientific knowledge, daily life experience, epistemological and social considerations intersect: Students' argumentation in group discussions on a socio-scientific issue. Research in Science Education, 38(1), 67-90. https://doi.org/10.1007/s11165-007-9040-2

Arslan, A. (2009). Yapılandırmacı öğrenme yaklaşımı ve Türkçe öğretimi. Atatürk Üniversitesi Sosyal Bilimler Enstitüsü Dergisi, 13(1), 143-154.

Aslan, S. (2014). Öğrencilerin yazılı bilimsel argüman oluşturma ve değerlendirme becerilerinin incelenmesi. Eğitimde Kuram ve Uygulama, 10(1), 41-74.

Ayas, A., Ünal, S., \& Sevim, S. (2004). Hidrojen bağı ile ilgili öğrencilerdeki kavram yanılgıları. XII. Eğitim Bilimleri Kongresi Bildiriler, 2199-2219.

Aydeniz, M., \& Dogan, A. (2016). Exploring the impact of argumentation on pre-service science teachers' conceptual understanding of chemical equilibrium. Chemistry Education Research and Practice, 17, 111-119. https://doi.org/10.1039/C5RP00170F

M. E. B. (2018). Fen Bilimleri Dersi Öğretim Programı (Illkokul ve Ortaokul 3, 4, 5, 6, 7 ve 8. Sinıflar). Retrieved from http://mufredat. meb. gov. tr/ProgramDetay. aspx.

Balkıs, M. (2006). Öğretmen adaylarının davranışlarındaki erteleme eğiliminin, düşünme ve karar verme tarzları ile ilişkisi (Doctoral dissertation, DEÜ Eğitim Bilimleri Enstitüsü).

Celep, N. (2015). Argümantasyona dayalı sorgulayıcı eğitim modelinin 10. sınıf öğrencilerinin gaz kavramlarını anlamalarına etkisi (Yayınlanmamış doktora tezi). Orta Doğu Teknik Üniversitesi, Fen Bilimleri Enstitüsü, Ankara.

Chen, C. H., \& She, H. C. (2012). The Impact of Recurrent On-line Synchronous Scientific Argumentation on Students' Argumentation and Conceptual Change. Educational technology \& society, 15(1), 197-210.

Çiçekçi, O. (2008). İlköğretim okullarında görevli öğretmenlerin transgenik ürünler (GDO) konusundaki bilgilerinin ve görüşlerinin belirlenmesi. Gazi Üniversitesi, Eğitim Bilimleri Enstitüsü, Ankara.

Çiftçi, K., \& Terin, M. (2018). Üniversite öğrencilerinin genetiği değiştirilmiş ürünler konusundaki bilgi düzeyleri: Ege Üniversitesi Örneği. https://doi.org/10.18092/ulikidince.354519

Demir, A., \& Pala, A. (2007). Genetiği değiştirilmiş organizmalara toplumun bakış açısı. Hayvansal Üretim, 48(1).

Demirci, C. (2009). Constructıvıst learnıng approach in science teachıng. Hacettepe Üniversitesi Eğitim Fakültesi Dergisi, 37(37), 24-35.

Demircioğlu, H., \& Geban, Ö. (1996). Fen bilgisi öğretiminde bilgisayar destekli öğretim ve geleneksel problem çözme etkinliklerinin ders başarısı bakımından karşılaştııılması. Hacettepe Üniversitesi Eğitim Fakültesi Dergisi, 12(12).

Demiral, Ü., \& Türkmenoğlu, H. (2018). Fen bilgisi öğretmen adaylarının sosyobilimsel bir konuda karar verme stratejilerinin alan bilgileriyle ilişkisi: Uludağ Üniversitesi Eğitim Fakültesi Dergisi.

Dori, Y. J., Tal, R. T., \& Tsaushu, M. (2003). Learning and assessing biotechnology topics through case studies with built-in dilemmas.

Driver, R., Newton, P., \& Osborne, J. (2000). Establishing the norms of scientific argumentation in classrooms. Science education, 84(3), 287-312. https://doi.org/10.1002/(SICI)1098-237X(200005)84:3<287::AID-SCE1>3.0.CO;2-A

Gökmen, A., \& Ekici, G. (2012). Ortaöğretim öğrencilerinin biyoloji öz-yeterlik alg1 düzeyleriyle öğrenme stilleri ilişkisinin değe. Gazi Üniversitesi Gazi Eğitim Fakültesi Dergisi, 32(3).

Erduran, S., Simon, S., \& Osborne, J. (2004). TAPping into argumentation: Developments in the application of Toulmin's argument pattern for studying science discourse. Science education, 88(6), 915-933. 
https://doi.org/10.1002/sce.20012

Erduran, S., \& Jiménez-Aleixandre, M. P. (2008). Argumentation in science education. Perspectives from classroom-Based Research. Dordre-cht: Springer.

Grace, M. (2009). Developing high quality decision-Making discussions about biological conservation in a normal classroom setting. International Journal of Science Education, 31(4), 551-570. https://doi.org/10.1080/09500690701744595

Jimenez-Aleixandre, M. P., \& Erduran, S. (2008). Argumentation in science education: An overview. In S. Erduran \& M. P. Jiménez-Aleixandre (Eds.), Argumentation in science education: Perspectives from classroom-based research (pp. 3-27). Dordrecht, The Netherlands: Springer. https://doi.org/10.1007/978-1-4020-6670-2_1

Jho, H., Yoon, H. G., \& Kim, M. (2014). The relationship of science knowledge, attitude and decision making on socio-scientific issues: The case study of students' debates on a nuclear power plant in Korea. Science \& Education, 23(5), 1131-1151. https://doi.org/10.1007/s11191-013-9652-z

Karaaslan, Z. (2017). Fen alanı öğretmen adaylarının genetiği değiştirilmiş organizmalara (gdo) ilişkin metaforları ve görsel imajları. Yayınlanmamış Yüksek Lisans Tezi. Dicle Üniversitesi Eğitim Bilimleri Enstitüsü Matematik ve Fen Bilimleri Eğitimi Ana Bilim Dalı.

Kardeş, N. (2013). Fen eğitiminde argümantasyon odaklı öğretimin öğrencilerin karar verme ve problem çözme becerilerine etkisi (Master's thesis, ESOGÜ, Eğitim Bilimleri Enstitüsü).

Kaya, O. N., \& Kılıç, Z. (2008). Etkin bir fen öğretimi için tartışmacı söylev. Ahi Evran Üniversitesi Kırşehir Ĕ̈itim Fakültesi Dergisi, 9(3), 89-100.

Koçyiğit, A. (2015). Fen Bilimleri Öğretmenlerinin Genetiği Değiştirilmiş Organizmalar (GDO) ve Ürünleri Konusunda Bilgi Düzeyleri, Öz Yeterlik İnançları, Tutum ve Risk Algılarının Belirlenmesi. Yayımlanmamış Yüksek Lisans Tezi. Ondokuz Mayıs Üniversitesi, Eğitim Bilimleri Enstitüsü, Samsun.

Nussbaum, E. M. \& Sinatra, G. M. (2003). Argument and conceptual engagement. Contemporary Educational Psychology, 28(3), 384-395. https://doi.org/10.1016/S0361-476X(02)00038-3

Öztürk, M. (2013). Argümantasyonun kavramsal anlamaya, tartışmacı tutum ve özyeterlik inancına etkisi (Yayınlanmamış yüksek lisans tezi). Pamukkale Üniversitesi, Eğitim Bilimleri Enstitüsü, Denizli.

Patronis, T., Potari, D., \& Spiliotopoulou, V. (1999). Students' argumentation in decision-making on a socio-scientific issue: implications for teaching. International Journal of Science Education, 21(7), 745-754. https://doi.org/10.1080/095006999290408

Sadler, T. D. (2004). Informal reasoning regarding SSI: A critical review of research. Journal of Research in Science Teaching. https://doi.org/10.1002/tea.20009

Sadler, T. D., \& Zeidler, D. L. (2005). Patterns of informal reasoning in the context of socioscientific decision making. Journal of Research in Science Teaching: The Official Journal of the National Association for Research in Science Teaching, 42(1), 112-138. https://doi.org/10.1002/tea.20042

Sadler, T. D., \& Zeidler, D. L. (2005b). The significance of content knowledge for informal reasoning regarding SSI: Applying genetics knowledge to genetic engineering issues. Science Education, 89, 71-93. https://doi.org/10.1002/sce.20023

Scott, S. G., \& Bruce, R. A. (1995). Decision-making style: The development and assessment of a new measure. Educational and psychological measurement, 55(5). https://doi.org/10.1177/0013164495055005017

Sevim, S., \& Tarım, S. S. (2017). Comparison of the Conceptual Change of Analogies and Conceptual Change Texts in Eliminating Students' Alternative Conceptions for Acids and Bases. Turkish Journal of Teacher Education, 6(1).

Sevim, S. (2013). Promoting Conceptual Change in Science Which is More Effective: Conceptual Change Text or Analogy. Journal of Turkish Science Education, 10(3).

Simon, S. (2008). Using Toulmin's argument pattern in the evaluation of argumentation in school science. International Journal of Research \& Method in Education, 31(3), 277-289. https://doi.org/10.1080/17437270802417176

Simonneaux, L. (2001). Role-play or debate to promote students' argumentation and justification on an issue in 
animal transgenesis. International Journal of Science Education, 23(9), 903-927. https://doi.org/10.1080/09500690010016076

Soysal, Y. (2012). Sosyobilimsel argümantasyon kalitesine alan bilgisi düzeyinin etkisi: Genetiği değiştirilmiş organizmalar. Abant Izzet Baysal University, Turkey.

Tatar, N., Feyzioğlu, E. Y., Buldur, S., \& Aydoğdu, B. (2014). Fen bilgisi öğretmen adaylarının araştırmaya dayalı eğitime yönelik algıları:"Bilimsel Araştırmanın İlkeleri” Ölçeği. Ondokuz Mayıs Üniversitesi Ĕgitim Fakültesi Dergisi, 33(2), 577-592.

Taşdelen, A. (2002). Öğretmen adaylarının farklı psiko sosyal Variablelere göre karar verme stilleri. Doktora Tezi. Dokuz Eylül Üniversitesi, Eğitim Bilimleri Enstitüsü, İzmir.

Tonus, F. (2012). Argümantasyona dayalı ögretimin ilköğretim ögrencilerinin eleştirel düşünme ve karar verme becerileri üzerine etkisi. Yayımlanmamış yüksek lisans tezi, Hacettepe Üniversitesi, Ankara.

Topçu, M. S., Muğaloğlu, E. Z., \& Güven, D. (2014). Fen eğitiminde sosyobilimsel konular: Türkiye örneği. Kuram ve Uygulamada Ĕ̈itim Bilimleri, 14(6), 1-22.

Topçu, M. S. (2008). Fen ögretmen adaylarının sosyobilimsel konular hakkındaki kritik dü̈sünme yetenekleri ve bu yetenekleri etkileyen faktörler. Orta Doğu Teknik Üniversitesi Sosyal Bilimler Enstitüsü, Ankara.

Toulmin, S. E. (1958). The use of argument. Cambridge University Press.

Tümay, H. (2008). Argümantasyon odaklı kimya öğretimi. Yayınlanmamış Yüksek Lisans Tezi. Gazi Üniversitesi Eğitim Bilimler Enstitüsü, Ankara.

Tümay, H., \& Köseoğlu, F. (2011). Kimya öğretmen adaylarının argümantasyon odaklı öğretim konusunda anlayığlarının geliştirilmesi. Türk Fen Eğitimi Dergisi, 8, 105-119.

Uzogara, S. G. (2000). The impact of genetic modification of human foods in the 21st century: A review. Biotechnology advances, 18(3), 179-206. https://doi.org/10.1016/S0734-9750(00)00033-1

Zhou, G. (2010). Conceptual Change in Science: A Process of Argumentation. Eurasia Journal of Mathematics, Science \& Technology Education, 6(2). https://doi.org/10.12973/ejmste/75231

\section{Copyrights}

Copyright for this article is retained by the author(s), with first publication rights granted to the journal.

This is an open-access article distributed under the terms and conditions of the Creative Commons Attribution license (http://creativecommons.org/licenses/by/4.0/). 